\title{
HPV prevalence and risk of pre-cancer and cancer in regular immigrants in ltaly: results from HPV DNA test-based screening pilot programs
}

\author{
Cinzia Campari ${ }^{1,2}$, Chiara Fedato ${ }^{3}$, Alessio Petrellii, Manuel Zorzi ${ }^{4}$, Carla Cogo $^{5}$, Adele Caprioglio ${ }^{6}$, Federica Gallo ${ }^{6}$, \\ Livia Giordano ${ }^{6}$, Serena Domenighini ${ }^{7}$, Luigi Pasquale ${ }^{7}$, Sonia Prandi ${ }^{8}$, Marco Zappa $^{9}$, Paolo Giorgi Rossi ${ }^{2,10^{*}}$ \\ and the GISCi Migrant Working Group
}

\begin{abstract}
Immigrants from low- and medium-income countries have a higher risk of cervical cancer due both to barriers in access to screening and to higher human papillomavirus (HPV) prevalence.

In the near future many screening programmes in industrialised countries will replace Pap test with HPV as primary test. In order to plan future interventions, it is essential to understand how the HPV screening performs in immigrant women.

Methods: We conducted a survey on the main performance indicators from some of the HPV DNA-based pilot programmes in Italy, comparing regular immigrant women, identified as women resident in Italy who were born abroad, with women who were born in Italy. All the programmes applied the same protocol, with HPV as stand-alone test starting for women of 25 or 35 to 64 years of age. Cytology triage is performed for positive women; those ASC-US or more severe are referred directly to colposcopy; negative women are referred to repeat HPV after one year.

Results: Overall, 162,829 women were invited, of whom 22,814 were born abroad. Participation was higher for Italy-born than born abroad (52.2\% vs. 43.6\%), particularly for women over 45 years. HPV positivity rate was higher in immigrants: $7.8 \%$ vs. 6.1\%, age-adjusted Relative Risk (age-adj RR) 1.18, 95\% confidence interval (95\% Cl) 1.13-1.22. The proportion of women with positive cytology triage was similar in the two groups (42\%). Cervical Intraepithelial Neoplasia (CIN) grade 2 or more severe detection rate was higher for born abroad (age-adj RR 1.65, 95\% Cl 1.45-1.89). The difference was stronger when considering only CIN3 or more severe (age-adj RR 2.29, 95\% Cl 1.90-2.75). Both HPV positivity and CIN2 or more severe detection rate had a different age curve in born abroad compared with Italy-born: in the former, the risk was almost flat, while in the latter it declined rapidly with age.
\end{abstract}

Conclusion: Compliance with HPV screening is lower for migrant women, who are affected by higher HPV positivity and CIN3 cancer detection rates.

\section{Introduction}

Persistent infection with oncogenic HPV types is the necessary, but not sufficient, cause of cervical cancer $[1,2]$. Wide differences in cervical cancer incidence and mortality have been observed around the world, with more than $85 \%$ of invasive cancers occurring in lowand middle-income countries [3]. The differences in

\footnotetext{
* Correspondence: paolo.giorgirossi@ausl.re.it

${ }^{2}$ IRCCS-Arcispedale Santa Maria Nuova, Reggio Emilia, Italy

${ }^{10}$ Servizio Interaziendale di Epidemiologia, AUSL, Reggio Emilia, Italy

Full list of author information is available at the end of the article
}

cancer incidence are mostly related to the diffusion of Pap test use and screening programmes [4-6].

Several studies have shown that migrant women from low- and medium- income countries have higher risk of cervical cancer [7-11] and usually maintain the same cervical cancer risk as that of their countries of origin for several years [12-15]. Both of the main determinants of cervical cancer can be related to the differential risk in immigrant women: many countries of origin have high prevalence of HPV infection [16,17]; Pap test coverage in migrant women is lower than in native women because

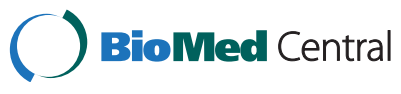

(c) 2015 Campari et al.; licensee BioMed Central. This is an Open Access article distributed under the terms of the Creative Commons Attribution License (http://creativecommons.org/licenses/by/4.0), which permits unrestricted use, distribution, and reproduction in any medium, provided the original work is properly credited. The Creative Commons Public Domain Dedication waiver (http://creativecommons.org/publicdomain/zero/1.0/) applies to the data made available in this article, unless otherwise stated. 
the diffusion of screening in their Countries of origin is very low [17] and because there could be several barriers to screening access in the host country [5,18-22].

Migration in Italy is a relatively recent phenomenon: in 1991, foreigners resident in Italy were less than $1 \%$ of the total population while in 2011 they were $7.5 \%$, with some cities over $16 \%$. Most of immigrant women in Italy are in the target age of cervical cancer screening [23,24].

Screening with HPV DNA as primary test has been demonstrated to be more effective in preventing cancer [25]. Many international guidelines are now introducing HPV test as primary screening test [26-30].

Screening programmes in Italy cover the vast majority of the resident population, without any difference with regard to citizenship [31]. In 2007, the first pilot programme using HPV DNA as primary screening test was implemented [32], followed by several other experiences in 2009-10 [33-36]. All the screening programmes, including HPV DNA pilot programmes, systematically collect information about invitations, test results, colposcopy and histology, and participate in a national survey $[37,38]$. In 2012, the survey included a focus on immigrant women.

\section{Objective}

In this paper we compare the screening results in 7 HPV-based pilot screening programmes in foreign-born vs. Italy-born women.

\section{Materials and methods \\ Setting}

In Italy, according to the European Commission recommendations (2003) [39], the Regional Health Systems are committed to organize screening programmes that actively invite the target female population. The national guidelines recommend a Pap test every three years for women aged 25-64 years. All women resident must be invited and all screening tests, ascertainments and treatments are free of charge.

Since 2007, after the publication of the results of three large randomised trials on HPV DNA as primary test [40-42], some Local Health Authorities started HPV DNA-based pilot programmes. All the programmes adopted the same protocol: [43] HPV DNA as primary test, followed by triage with cytology: HPV positive $(\mathrm{HPV}+)$ and cytology positive (cyto+) prompted immediate colposcopy, while HPV+ cytology negative (cyto-) prompted one-year follow up with HPV. Some pilot programmes adopted this strategy for women age 2564 years, others for women age 35 to 64 only. The interval for HPV negative (HPV-) women was 3 years for all women recruited until 2012. Women receive the test results by letter if negative; they are contacted by phone in case of positivity (and also by letter, in some programmes only if there is no answer; in other programmes, always) to make an appointment for colposcopy. In some programmes women who are HPV positive and cytology negative are contacted only by letter while in some other programmes they are contacted by phone. In any case women are actively contacted to communicate the results of the screening tests.

Some of the projects were randomised pragmatic trials; the others were intervention studies with historical or geographical controls. The pilot programmes tested feasibility, organizational impact, acceptability (for operators and women), compliance with invitation and follow-up protocols, performance of cytology triage and, finally, they collected field information for economic and budget impact analysis.

All the projects were approved by the local Ethics Committees or were established by law by the regional health authority.

The Osservatorio Nazionale Screening, supported by the Centro per la Prevenzione Oncologica (CPO), Piedmont, annually collects aggregated data from all the Italian screening programmes, whose results are published in an annual national report [37,38].

The survey methods were developed by the GISCi (Gruppo Italiano per lo Screening Cervicale) in 1999 [44], and are consistent with the minimum dataset of indicators of the European guidelines [45].

From 2012, the survey collected information from the HPV DNA-based screening.

\section{The migrant survey}

In 2012, the GISCi promoted the collection of information on immigrant women inside the national survey. The country of birth was used to identify the migrant status. Only two programmes (Reggio Emilia and Torino) classified the countries as low- and medium-income or other (i.e., high income), according to the classification of "high migration pressure countries" of the Italian Ministry of Health [46].

Data were collected with the same form as the official survey and were disaggregated by age and migration status, while they did not distinguish women at first vs. subsequent screening episodes. Furthermore, we requested data for the three-year period 2009-11.

\section{HPV DNA molecular analyses}

HPV test was performed on liquid based cytology samples or on samples specific to HPV test. In the latter case, a smear was obtained and fixed before taking the sample for molecular testing.

All the programmes used Hybrid Capture 2 (Qiagen), on both liquid based cytology (PreservCyt) or on Standard Transport Medium (STM). For programmes using two samples (cytology and STM) the denaturation and hybridization was directly performed on the sampling 
medium. For programmes using liquid based cytology, $4 \mathrm{ml}$ of PreservCyt were transferred for the conversion according to the manufacturer's instructions. HPV results were classified as positive or negative for highrisk types. The types included were $16,18,31,33,35$, $39,45,51,52,56,58,59$, and 68 .

\section{Cytology}

In the programmes using conventional smears, only the slides of $\mathrm{HPV}+$ women were stained and interpreted. In the case of liquid based cytology, the slide was prepared from residual material after $\mathrm{HPV}$ testing only when $\mathrm{HPV}+$. Cytology results were classified according to TBS 2001. All the programmes referred women with ASC-US or more severe cytology to colposcopy. Women with an unsatisfactory cytology were referred to colposcopy in some programmes, while cytology was repeated on a new sample in others.

\section{Analysis}

We present the set of the indicators routinely used to evaluate the performance of screening programmes, stratified by country of birth (Italy vs. other countries). For two programmes, migrants were further stratified in women from low/medium income and from high income countries. The indicators included participation (crude and adjusted - i.e., accounting for the undelivered mails), HPV positivity, cytology triage results, recall rate to colposcopy, compliance with colposcopy, detection rate for cervical intraepithelial neoplasia grade 2 (CIN2), CIN grade 3 (including Adenocarcinoma in situ, CIN3), and for cancer at baseline (i.e., not including one-year follow up for HPV+ cytology- women). Except for participation and compliance to colposcopy, all indicators were age-standardised using the Italy-born screened women as standard population. For participation, cytology results, and detection rate, we calculated age-adjusted relative risks (age-adj RR) with 95\% confidence intervals $(95 \% \mathrm{CI})$.

\section{Results}

Seven of the 19 pilot projects active in Italy in 2012 participated in the survey. The duration of the study period ranged from one to three years; the survey was restricted to screening results of women invited between 1 January 2009 and 31 December 2011. Overall, the pilot programmes invited 162,829 women, of whom 22,814 were immigrant (Table 1).

In the programmes that distinguished women from low/medium income countries vs. those from high income countries, the latter accounted for a small proportion of all the migrants (9.4\%).

Women born abroad invited for screening were on average younger than Italians (mean age 43.3 vs. 46.7 years, respectively). The participation was lower in born abroad than in Italy-born women (43.6\% vs. 52.2\%), though the difference was noticeable only in women aged $\geq 40$ years (Figure 1).

The overall participation rate in women from highincome countries was lower than the average of women born abroad ( $44 \%$ vs $47 \%$ and $61 \%$ vs $65 \%$ in Turin and Reggio Emilia, respectively).

The overall age-adjusted HPV positivity rate was higher in born abroad than in Italy-born women (age-adj RR $1.18,95 \%$ CI 1.13-1.22), with a different shape by age (Figure 2): the curve for Italians decreased sharply with age, while the migrants showed a modest decrease between ages 25 and 40 and a second peak after menopause. As a result, young women born abroad had a lower HPV prevalence than did young Italy-born women. Women born in high income countries showed a prevalence curve very similar to Italians.

Among HPV+ women, the prevalence of cyto + was similar in migrants and Italians, resulting in higher referral to both colposcopy and one-year follow up for migrants. Women born abroad had a higher proportion of high-grade cytology (H-SIL, ASC-H, and cancer) than

Table 1 Characteristics of the participating centres: target population, proportion of foreigners, study period, and available information for immigration status

\begin{tabular}{|c|c|c|c|c|c|c|c|c|c|}
\hline \multirow[b]{2}{*}{ Centre } & \multirow[b]{2}{*}{$\begin{array}{l}\text { Target population } \\
\text { for HPV screening } \\
\text { (Years) }\end{array}$} & \multirow[b]{2}{*}{$\begin{array}{l}\text { Invited } \\
\text { population (N) }\end{array}$} & \multirow[b]{2}{*}{$\begin{array}{l}\text { Proportion of } \\
\text { born abroad (\%) }\end{array}$} & \multicolumn{3}{|c|}{ Period } & \multicolumn{3}{|c|}{ Information about immigration status } \\
\hline & & & & 2009 & 2010 & 2011 & $\begin{array}{l}\text { Place } \\
\text { of birth }\end{array}$ & Citizenship & $\begin{array}{l}\text { Identifying high } \\
\text { migration pressure } \\
\text { countries }\end{array}$ \\
\hline Torino & $35-64$ & 41,440 & 18.1 & + & + & + & + & + & + \\
\hline Alta Padovana & $25-64$ & 22,826 & 15.4 & & & + & + & + & \\
\hline Padova & $25-64$ & 15,459 & 15.4 & & & + & + & + & \\
\hline Este & $25-64$ & 31,963 & 8.9 & & + & + & + & + & \\
\hline Rovigo & $25-64$ & 15,534 & 11.4 & & & + & + & + & \\
\hline Adria & $25-64$ & 7,464 & 8.5 & & & + & + & & \\
\hline Reggio Emilia & $35-64$ & 17,048 & 18.3 & & + & + & + & + & + \\
\hline Valcamonica & $25-64$ & 11,095 & 9.5 & & & + & + & & \\
\hline
\end{tabular}




\section{A}

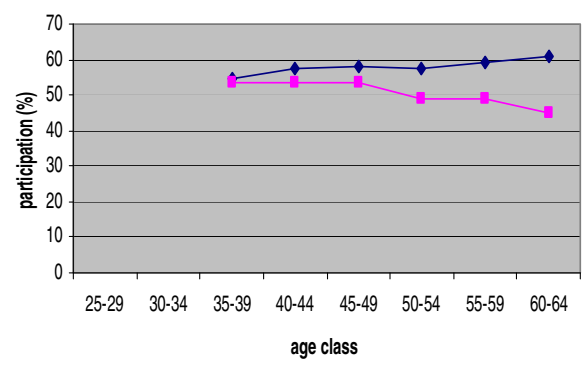

\section{B}

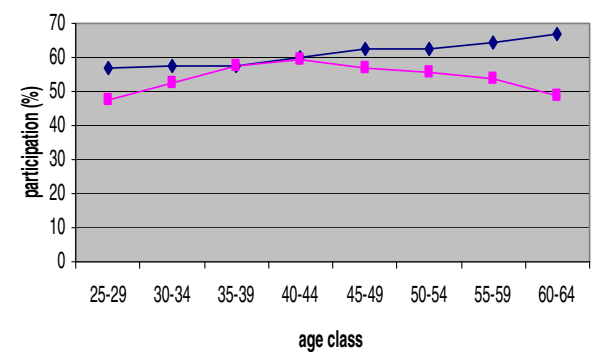

Italy-born

-

Figure 1 Participation in HPV-based cervical cancer screening by age and place of birth. A. Torino and Reggio Emilia, target age 35-64. B. Veneto and Valcamonica, target age 25-64.

did Italians $(10.1 \%$ vs. $5.9 \%$ of the HPV+ women, $\mathrm{p}=$ 0.0001) (Table 2).

Compliance to colposcopy referral was high in both groups (91.7\% and $93.5 \%$ for immigrants and Italians, respectively).

The detection rate of $\mathrm{CIN} 2+$ was higher for women born abroad than for Italians ( $8.2 \%$ vs. $4.7 \%$ ). The difference was entirely due to an excess of CIN3+ (age-adj RR 2.29, 95\% CI 1.90-2.75), while a negligible difference was observed for CIN2 (age-adj RR 1.07, 95\% CI 0.881.31) (Table 2). The detection rate was different also by age: the risk was lower for women born abroad than for Italians below age 30, while at older ages the risk decreased in Italians but remained stable in women born abroad, resulting in an excess of CIN2+ in the latter in women older than 40 years 40 (Figure 3). Women from high income countries showed an overall age-adjusted detection rate lower than that of Italians.

Five of the 15 cancers identified was found in women born abroad, who accounted for only $12 \%$ of the screened population. In fact, the cancer detection rate was about four times higher in women born abroad than in Italians (age-adj RR 3.7, 95\% CI 1.3-11.4).

\section{Discussion}

This is the first study reporting the results of several population-based screening programmes that adopted HPV DNA as primary screening stratified for migrant and native population in an industrialized country. In Italy, HPV DNA-based screening was implemented quite early: the first pilot programme started in 2007, [32] and in January 2013 the Ministry of Health adopted the HTA Italian report, [47] thus allowing the Public Health Service to introduce HPV DNA as primary screening.

\section{Participation}

Several of the HPV DNA test pilot programmes reported a slightly higher participation than that of Pap test-based programmes [32-36]. However, this increase is unlikely to reduce the gap in participation between Italians and immigrants. In fact, our survey detected a difference in participation between Italians and immigrants, both from high income and from low/medium income countries, similar or even higher than that observed in Pap test-based programmes [48].

Nevertheless, population-based screening programmes are effective interventions in reducing inequality in the

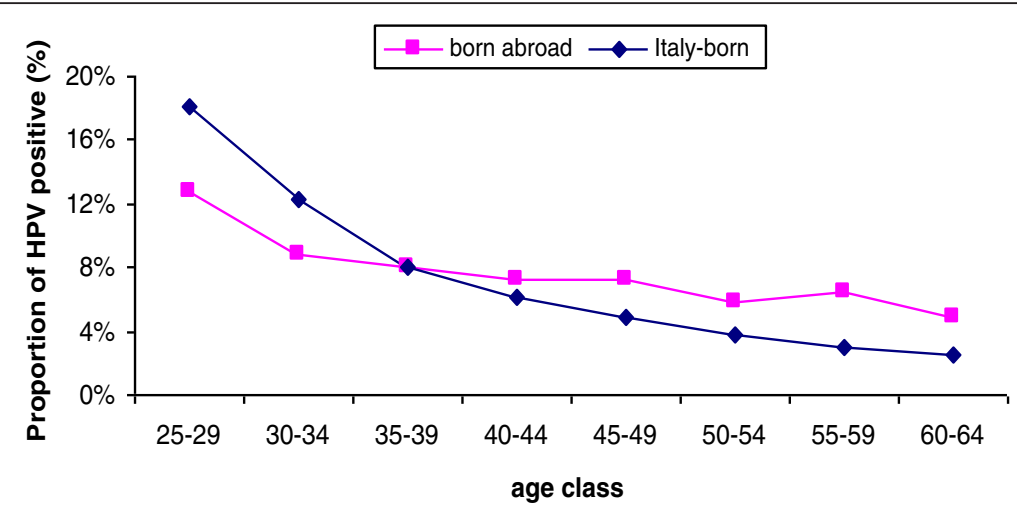

Figure 2 Proportion of women HPV positive (Hybrid Capture II, high-risk types) by age and place of birth. 
Table 2 Main data and principal performance indicators of seven Italian pilot programmes adopting HPV as primary screening test followed by cytology triage, by country of birth

\begin{tabular}{|c|c|c|c|c|c|c|c|c|}
\hline & \multirow{2}{*}{\multicolumn{2}{|c|}{ Italy-born }} & \multirow{2}{*}{\multicolumn{2}{|c|}{ Born abroad }} & \multicolumn{4}{|c|}{ Relative risk immigrants vs. Italians } \\
\hline & & & & & \multirow[t]{2}{*}{ Crude RR } & \multirow[t]{2}{*}{$95 \% \mathrm{Cl}$} & \multirow[t]{2}{*}{ Age adjusted RR } & \multirow[t]{2}{*}{$95 \% \mathrm{Cl}$} \\
\hline & $\bar{N}$ & $(\%)^{*}$ & $\mathrm{~N}$ & $(\%)^{*}$ & & & & \\
\hline Invited Population (N) & 140,015 & & 22,814 & & & & & \\
\hline Undelivered letters & 1,305 & 0.9 & 1196 & 5.2 & & & & \\
\hline Participants & 73,023 & 52.2 & 9941 & 43.6 & 0.84 & $(0.82-0.85)$ & & \\
\hline Participation excluding undelivered letters (\%) & & 52.6 & & 46.0 & 0.87 & $(0.86-0.89)$ & & \\
\hline HPV tests performed & 72,176 & & 9680 & & & & & \\
\hline HPV positive & 4,421 & 6.1 & 751 & 7.8 & 1.27 & $(1.18-1.36)$ & 1.18 & $(1.13-1.22)$ \\
\hline \multicolumn{9}{|l|}{ cytological triage* } \\
\hline Negative & 1,925 & 48.4 & 326 & 49.2 & & & & \\
\hline Inadequate & 180 & 4.5 & 24 & 3.6 & & & & \\
\hline ASC-US & 444 & 11.2 & 66 & 10.0 & & & & \\
\hline$A G C$ & 17 & 0.4 & 5 & 0.8 & & & & \\
\hline$L-S I L$ & 1,173 & 29.5 & 174 & 26.3 & & & & \\
\hline ASC-H & 74 & 1.9 & 22 & 3.3 & & & & \\
\hline$H-S I L$ & 158 & 4.0 & 42 & 6.3 & & & & \\
\hline Cancer & 3 & 0.1 & 3 & 0.5 & & & & \\
\hline Total ASC-US+ (\% of HPV positive) & 1,869 & 47.0 & 312 & 47.1 & 0.98 & $(0.87-1.07)$ & 0.95 & $(0.90-0.99)$ \\
\hline Referred to colposcopy & 1,968 & 2.7 & 324 & 3.3 & 1.23 & $(1.09-1.38)$ & 1.22 & $(1.09-1.37)$ \\
\hline Compliance to colposcopy & 1,840 & 93.5 & 297 & 91.7 & 0.98 & $(0.95-1.02)$ & & \\
\hline Detection rate for CIN3+ (\%o screened women) & 163 & 2.3 & 50 & 5.2 & 2.29 & $(1.67-3.14)$ & 2.29 & $(1.90-2.75)$ \\
\hline Detection rate for CIN2+ (\%o screened women) & 342 & 4.7 & 79 & 8.2 & 1.72 & $(1.35-2.20)$ & 1.65 & $(1.45-1.89)$ \\
\hline CIN2 & 179 & 52.3 & 29 & 36.7 & & & & \\
\hline CIN3 + adeno in situ & 153 & 44.7 & 45 & 56.7 & & & & \\
\hline Invasive Cancer & 10 & 5.6 & 5 & 17.2 & 3.73 & $(1.27-10.90)$ & 3.9 & $(1.33-11.41)$ \\
\hline Positive predictive value of colposcopy referral & & 18.6 & & 26.6 & 1.43 & $(1.16-1.77)$ & 1.38 & $(1.12-1.71)$ \\
\hline
\end{tabular}

*cytology triage results were missing for 447 and 89 women born in Italy and abroad, respectively.

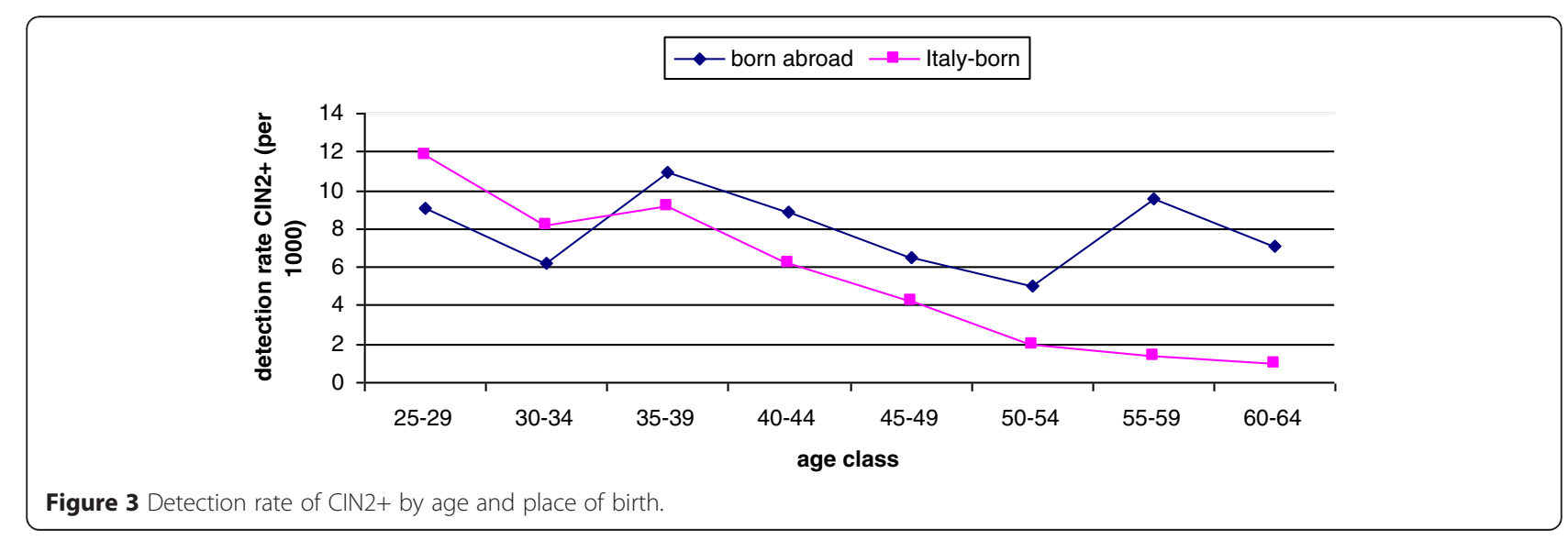


access to evidence-based prevention [49-51]. In Italy, the difference in Pap test coverage between Italians and immigrants is smaller in the regions where well-organized screening programmes are present, compared to those regions where screening programmes cannot regularly invite all the population and the access to Pap test is mainly spontaneous [52]. This effect occurs even when the participation is slightly lower for immigrants than for Italians, but given the much lower uptake of opportunistic screening by immigrants, organised programmes contribute to reducing inequality, which should be the case with HPV DNA-based screening as well.

\section{Prevalence of HPV infections and high-grade lesions}

The prevalence of HPV infection was higher in immigrants than in Italians. Also, the curve of prevalence by age was different in the two groups: the results in Italian women confirmed the prevalence curve already observed in previous population-based studies [53-55], with a constant decline with age, which was steep until age 40 and flatter from ages 45 to 65 . The prevalence in immigrants, instead, decreased slightly from ages 25 to 35 and then remained almost flat.

The curve in immigrants is similar to that of many low/medium income countries such as sub-Saharan Africa, central Asia, and Latin America [56], but not to some of other countries most represented among immigrants resident in Italy (e.g. Mediterranean Africa, the Middle East, and Indian sub-continent $[17,56]$. The foreign population in Italy is extremely heterogeneous in terms of country of origin: the first 5 countries (Romania, Albania, Morocco, China, and the Ukraine) account for only $50 \%$ of the foreign population [24]. Furthermore, the different populations are not evenly distributed by age [24]. Thus, the overall prevalence curve probably reflects the distribution by age of some communities with a very high prevalence in their countries of origin, such as sub-Saharan Africa and Eastern Europe, and of other communities with a low HPV prevalence, such as Mediterranean Africa and Indian sub-continent. The latter immigrants are younger, while women from Eastern Europe, an area with a very high prevalence, tend to be older.

It is worth noting that the overall proportion of cyto + among HPV+ women is very similar in Italians and immigrants, while the proportion of high-grade lesions is higher in immigrants. A higher proportion of women with high-grade cytology is consistent with a higher detection rate of CIN2+ and particularly of CIN3 in immigrants than in Italians. A ratio between high-grade and low-grade lesions in favour of high grade is probably linked to a lower uptake of screening among immigrants in the preceding years, both in their countries of origin and in Italy. This means that long-lasting and more severe lesions are detected. Indeed, a higher detection rate may be the consequence of both higher HPV prevalence and lower screening uptake in the preceding years.

All of the observed differences between immigrants and Italians suggest that the immigrant populations maintain the prevalence of their countries of origin for several years, particularly when migration is a relatively recent phenomenon (as it is in Italy). Many other studies have also observed this phenomenon when looking at HPV prevalence [16,57], cytological abnormalities $[18,19,48]$, and pre-cancer or cancer risk [5,7-15].

\section{Limits and strengths}

The country of birth, which we used as a proxy of the migration status, could misclassify women, thereby including many Italian women among the migrants. Nevertheless, even citizenship, unanimously considered a better proxy of migrant status in women aged 25-64, can misclassify a significant number of women who are married to Italians but who migrated to Italy relatively recently. Another Italian study compared cervical cancer screening indicators obtained using the country of birth or citizenship and found only minor differences [48]. We decided to use the country of birth because this information was more uniformly collected by the programmes and it was probably the most reliable.

Furthermore, only few programmes could distinguish women from low/medium income from those from high-income countries. All the analyses confirmed that, in Italy now, calculating the indicators for all the foreigners provides figures that substantially depict the health status of immigrants.

Differences between native and immigrant women tend to decrease with time after the arrival in the host country [15]. In the case of cervical cancer risk, it would be interesting to observe the time needed to reduce the gap in screening participation and in HPV prevalence. Unfortunately we do not have information on the length of stay in Italy.

On the other hand, the characteristics of immigrants from high-income countries were substantially comparable to those of Italians, with the exception of participation.

Another limit of this study is that we could not identify the exact country of origin. HPV prevalence differs in different areas and it would be important to distinguish between countries with high vs. low prevalence, in order to determine whether the prevalence of communities resident in Italy reflects the country of origin. Analyses by specific communities are necessary to better understand the epidemiology of HPV and cervical cancer in immigrants and to target public health interventions.

Furthermore, we could not distinguish between women at their first screening round and those who had already 
had a previous Pap test. On the other hand, it must be noted that almost all the women included in this survey were at their first HPV screening test.

Finally, screening programmes actively invite only women that are resident, or at least registered, in their catchment area, while irregular migrants and asylum seekers, who are surely more vulnerable than are regular residents, can only access screening spontaneously. Therefore we have information only on regular immigrants, registered as such. While citizens from outside of the European Union (i.e. all the regular immigrants but not tourists or those with a short-term or a study visa) must be registered residents, the same is not true for European Union citizens. However, since residents can obtain tax reductions, reduced fees for electricity, gas, water supplies, and so on, not being resident has many disadvantages. Thus, persons staying for a long time usually are registered as resident.

\section{Conclusions}

Immigrant women have a higher prevalence of HPV, a worse ratio of high-grade vs. low-grade lesions, and consequently a higher risk of cervical pre-cancer and cancer than do Italians. The prevalence of HPV seems to reflect that of their countries of origin. HPV DNAbased programmes are not likely to reduce the gap in participation in screening programmes between immigrants and Italians.

\section{Competing interests}

The authors declare that they have no competing interests.

\section{Authors' contributions}

$\mathrm{CCa}, \mathrm{CF}, \mathrm{MZO}, \mathrm{CCO}, \mathrm{MZa}$, and PGR conceived the study and designed the survey. CCa, CF, MZo, CCo, AC, FG, LG, SD, LP, and SP conducted the survey, collected data and performed local data analysis in each centre. CCa coordinated the data collection and data analyses at the national level. CCa and PGR performed the statistical analyses. CCa, PGR, and AP drafted the paper. MZo, MZa, and LG critically revised the manuscript. All the authors read and approved the paper.

\begin{abstract}
Acknowledgement
The GISCI Migrant Working Group:

Manuel Zorzi, Chiara Fedato, Carla Cogo, Regione Veneto; Roberta Castagno, Adele Caprioglio, Federica Gallo, Livia Giordano, Regione Piemonte; Maria Rosa Schivardi, Brescia; Serena Domenighini, Luigi Pasquale, Vallecamonica-Sebino; Giovanni Marazza, Eva Rossetti, Lodi; Emanuela Anghinoni, Elena Bianchera, Anna Laura Bozzeda, Maria Rosa Corradelli, Mantova; Mauro Palazzi, Claudia Imolesi, Cesena; Luigi Lombardozzi, Parma; Giancarla Monticelli, Debora Canuti, Rimini; Cinzia Campari, Sonia Prandi, Paolo Giorgi Rossi Reggio Emilia; Anna lossa, Carmen Beatriz Visioli, Firenze; Roberta Rosati, Grosseto; Daniela Giorgi, Lucca; Silvia Brezzi, Angela Brachini, Viterbo; Carla Bietta, Marco Petrella, Regione Umbria; Diego Baiocchi, Barbara Giordani, Alessandro Maltempi, Alessandra Barca, Regione Lazio; Alessio Petrelli, INMP.
\end{abstract}

\section{Funding}

The study was partially funded by the Italian Ministry of Health through a grant to the INMP, Istituto Nazionale per la promozione della salute delle popolazioni Migranti ed il contrasto delle malattie della Povertà, Rome, Italy.

\section{Author details}

'Staff Programmazione e Controllo, AUSL, Reggio Emilia, Italy.

${ }_{2}^{2}$ IRCCS-Arcispedale Santa Maria Nuova, Reggio Emilia, Italy. ${ }^{3}$ Coordinamento regionale screening oncologici, Regione Veneto, Venezia, Italy. ${ }^{4}$ INMP Istituto Nazionale per la promozione della salute delle popolazioni Migranti ed il contrasto delle malattie della Povertà, Rome, Italy. ${ }^{5}$ Registro Tumori del Veneto, Regione Veneto, Padova, Italy. ${ }^{6}$ Unità di Epidemiologia - CPO Piemonte, Torino, Italy. ${ }^{7}$ ASL Valle Camonica Sebino, Breno, BS, Italy. ${ }^{8}$ Patologia IRCCS-Arcispedale Santa Maria Nuova, Reggio Emilia, Italy. ${ }^{9}$ ISPO - Istituto per lo Studio e la Prevenzione Oncologica, Florence, Italy. ${ }^{10}$ Servizio Interaziendale di Epidemiologia, AUSL, Reggio Emilia, Italy.

Received: 20 February 2015 Accepted: 21 April 2015

Published online: 07 May 2015

\section{References}

1. IARC. Handbooks of cancer prevention. Cervix Cancer Screening. (Vol. 10). Lyon: IARC; 2005.

2. Walboomers JM, Jacobs MV, Manos MM, Bosch FX, Kummer JA, Shah KV, et al. Human papillomavirus is a necessary cause of invasive cervical cancer worldwide. J Pathol. 1999;189:12-9.

3. IARC. Globocan. Cancer Fact Sheet: Cervical Cancer Incidence and Mortality Worldwide in 2008. 2008. Available from: http://globocan.iarc.fr/Pages/ fact_sheets_cancer.aspx?cancer=cervix. Accessed April 24, 2015.

4. Vaccarella S, Lortet-Tieulent J, Plummer M, Franceschi S, Bray F. Worldwide trends in cervical cancer incidence: impact of screening against changes in disease risk factors. Eur J Cancer. 2013;49(15):3262-73.

5. Azerkan F, Sparén P, Sandin S, Tillgren P, Faxelid E, Zendehdel K. Cervical screening participation and risk among Swedish-born and immigrant women in Sweden. Int J Cancer. 2012;130:937-47.

6. Giorgi Rossi P, Ronco G. The Present and Future of Cervical Cancer Screening Programmes in Europe. Curr Pharm Des. 2013;19(8):1490-7.

7. Di Felice E, Caroli S, Paterlini L, Campari C, Prandi S, Giorgi Rossi P. Cervical cancer epidemiology in foreign women in Northern Italy: role of HPV prevalence in country of origin. Eur J Cancer Prev. 2015;24(3):223-30. doi:10.1097/CEJ.0000000000000137.

8. Crocetti E, Manneschi G, Visioli CB, Zappa M. Risk of invasive cervical cancer and cervical intraepithelial neoplasia grade III in central Italy by area of birth. J Med Screen. 2010;17(2):87-90.

9. McDermott S, Desmeules M, Lewis R, Gold J, Payne J, Lafrance B, et al. Cancer incidence among Canadian immigrants, 1980-1998: results from a national cohort study. J Immigr Minor Health. 2011;13(1):15-26.

10. Arnold M, Aarts MJ, van der Aa M, Visser O, Coebergh JW. Investigating cervical, oesophageal and colon cancer risk and survival among migrants in The Netherlands. Eur J Public Health. 2013;23(5):867-73. doi:10.1093/eurpub/cks146.

11. Hemminki K, Li X. Cancer risks in Nordic immigrants and their offspring in Sweden. Eur J Cancer. 2002;38(18):2428-34.

12. Arnold $\mathrm{M}$, Razum $\mathrm{O}$, Coebergh JW. Cancer risk diversity in non-western migrants to Europe: an overview of the literature. Eur J Cancer. 2010;46(14):2647-59.

13. Mousavi SM, Sundquist K, Hemminki K. Morbidity and mortality in gynecological cancers among first- and second-generation immigrants in Sweden. Int J Cancer. 2012;131(2):497-504.

14. Beiki O, Allebeck P, Nordqvist T, Moradi T. Cervical, endometrial and ovarian cancers among immigrants in Sweden: importance of age at migration and duration of residence. Eur J Cancer. 2009;45(1):107-18.

15. Azerkan F, Sparén P, Sandin S, Tillgren P, Faxelid E, Zendehdel K. Risk of cervical cancer among immigrants by age at immigration and follow-up time in Sweden, from 1968 to 2004. Int J Cancer. 2008;123(11):2664-70.

16. Tornesello ML, Cassese R, De Rosa N, Buonaguro L, Masucci A, Vallefuoco G, et al. High prevalence of human papillomavirus infection in Eastern European and West African women immigrants in South Italy. APMIS. 2011;119(10):701-9.

17. WHO-ICO. Summary report about HPV infection and cervical cancer, 2010 edition. Available from: http://www.hpvcentre.net/summaryreport.php. Accessed April 24, 2015.

18. Visioli CB, Crocetti E, Zappa M, lossa A, Andersson KL, Bulgaresi P, et al. Participation and Risk of High Grade Cytological Lesions Among Immigrants and Italian-Born Women in an Organized Cervical Cancer Screening Programme in Central Italy. J Immigr Minor Health. 2014. [Epub ahead of print] 
19. Vallesi G, Bietta C, Marri M, Petrella M. Provenienza da Paesi a forte pressione migratoria e partecipazione allo screening citologico nell'AUSL2 dell'Umbria. Impatto sulla probabilità di presentare lesioni di alto grado e tumori del collo dell'utero. Epidemiol Prev. 2012;36(2):95-9.

20. Behbakht K, Lynch A, Teal S, Degeest K, Massad S. Social and cultural barriers to Papanicolaou test screening in an urban population. Obstet Gynecol. 2004;104:1355-61.

21. Chiu LF. Inequalities of access to cancer screening: a literature review. Cancer Screening Series $N^{\circ} 1$. Sheffield: NHS Cancer Screening Programmes; 2003. Available on the web at: http://www.cancerscreening.nhs.uk/ publications/cs1.pdf. Accessed April 29, 2015.

22. Van der Aa MA, Siesling S, Louwman MW, Visser O, Pukkala E, Coebergh JW. Geographical relationships between sociodemographic factors and incidence of cervical cancer in the Netherlands 1989-2003. Eur J Cancer Prev. 2008;17(5):453-9.

23. Istituto Nazionale di Statistica (ISTAT). Gli stranieri in Italia: analisi dei dati censuari. 14 Censimento generale della popolazione e delle abitazioni del 21 ottobre 2001 Roma, ISTAT (Approfondimenti tematici), Maggio 2006. Available from: http://www3.istat.it/dati/catalogo/20071109 04/ stranieri_in_italia_analisi_dati_censuari.pdf. Accessed April 29, 2015.

24. Istituto Nazionale di Statistica (ISTAT). Resident foreigners [database online] Available from: http://www.demo.istat.it. Accessed April 29, 2015.

25. Ronco G, Dillner J, Elfström KM, Tunesi S, Snijders PJF, Arbyn M, et al. Efficacy of HPV-based screening for preventing invasive cervical cancer: follow-up of European randomised controlled trials. Lancet. 2014. doi:10.1016/S0140-6736(13)62218-7

26. Saslow D, Solomon D, Lawson HW, Killackey M, Kulasingam SL, Cain J, et al. American Cancer Society, American Society for Colposcopy and Cervical Pathology, and American Society for Clinical Pathology screening guidelines for the prevention and early detection of cervical cancer. Am J Clin Pathol. 2012;137(4):516-42.

27. Moyer VA, Preventive Task Force US. Screening for cervical cancer: U.S Preventive Services Task Force recommendation statement. Ann Intern Med. 2012;156(12):880-91.

28. Health Council of the Netherlands. Population screening for cervical cancer. The Hague: Health Council of the Netherlands; 2011. publication no. 2011/07E.

29. Ronco S, Accetta G, Angeloni C, Arbyn M, Barzon L, Biggeri A, et al. Health technology assessment report. Use of liquid-based cytology for cervical cancer precursors screening. Epidemiol Prev. 2012;36(5Suppl2):e1-33.

30. Arbyn M, Haelens A, Desomer A, Verdoodt F, Thiry N, Francart J, et al. Cervical cancer screening programme and Human Papillomavirus (HPV) testing, part II: Update on HPV primary screening. Health Technology Assessment (HTA). Brussels: Belgian Health Care Knowledge Centre (KCE); 2015. KCE Reports 238. D/2015/10.273/17.

31. Ministero della Salute, Direzione Generale della Prevenzione. Raccomandazioni per la pianificazione e l'esecuzione degli screening di popolazione per la prevenzione del cancro della mammella, del cancro della cervice uterina e del cancro del colon retto. Roma: Ministero della Salute; 2005. http://www.osservatorionazionalescreening.it/ons/ documentazione/raccomandazioni/screening_vers_completa.pdf. Accessed April 29, 2015

32. Confortini M, Giorgi Rossi P, Barbarino P, Passarelli AM, Orzella L, Tufi MC. Screening for cervical cancer with the Human papillomavirus test in an area of central Italy with no previous active cytological screening programme. J Med Screen. 2010;17(2):79-86

33. Pasquale L, Giorgi Rossi P, Carozzi F, Pedretti C, Ruggeri C, Scalvinoni V, et al. Screening for cervical cancer with HPV testing: performance and organizational impact of the Valcamonica screening programme, Northern Italy. J Med Screen. 2015;22(1):38-48. doi:10.1177/0969141314561707.

34. Zorzi M, Del Mistro A, Farruggio A, de'Bartolomeis L, Frayle-Salamanca H, Baboci $L$, et al. Use of a high-risk human papillomavirus DNA test as the primary test in a cervical cancer screening programme: a population-based cohort study. BJOG. 2013;120(10):1260-7.

35. Del Mistro A, Frayle H, Ferro A, Callegaro S, Del Sole A, Stomeo A, et al. Cervical cancer screening by high risk HPV testing in routine practice: results at one year recall of high risk HPV-positive and cytology-negative women. J Med Screen. 2014;21(1):30-7.

36. Ronco G, Giorgi-Rossi P, Giubilato P, Del Mistro A, Zappa M, Carozzi F, et al A first survey of HPV-based cervical cancer screening in routine activity in Italy. Epidemiol Prev. 2015. In press.
37. Giorgi Rossi P, Federici A, Zappa M. Il sistema di indicatori per il monitoraggio e la valutazione dei programmi di screening e i possibili sviluppi per la valutazione dello screening spontaneo. Pathologica. 2013;105:83-5.

38. Ronco G, Giubilato P, Carozzi F, Maina G, Giorgi-Rossi P, Zappa M, et al. Extension of organised cervical cancer screening programmes in Italy and their process indicators, 2011-12 activity. Epidemiol Prev. 2015. In press.

39. Council Recommendation 2 December 2003 on cancer screening. 2003/878/EC

40. Naucler P, Ryd W, Törnberg S, Strand A, Wadell G, Elfgren K, et al. Human papillomavirus and Papanicolaou tests to screen for cervical cancer. N Engl J Med. 2007;357(16):1589-97.

41. Bulkmans NW, Berkhof J, Rozendaal L, van Kemenade FJ, Boeke AJ, Bulk S, et al. Human papillomavirus DNA testing for the detection of cervical intraepithelial neoplasia grade 3 and cancer: 5-year follow-up of a randomised controlled implementation trial. Lancet. 2007;24(370):1764-72

42. Ronco G, Segnan N, Giorgi-Rossi P, Zappa M, Casadei GP, Carozzi F, et al. Human Papillomavirus testing and liquid-based cytology in primary cervical screening: results at recruitment from the NTCC randomized controlled trial. J Natl Cancer Inst. 2006;98(11):765-74.

43. GISCi, Gruppo Italiano Screening Cervicale. Raccomandazioni sul test HR-HPV come test di screening primario e rivisitazione del ruolo del Pap test. Available on the web: http://www.gisci.it/documenti/documenti_gisci/documento_hpv.pdf. Accessed April 29, 2015.

44. Ronco G, Zappa M, Naldoni C, lossa A, Berrino F, Anghinoni E, et al. GISCi Gruppo Italiano Screening del Cervicocarcinoma. Indicators and standards for evaluating the program process for cervical cancer screening. Operation manual. Italian Group for Cervical Carcinoma Screening. Epidemiol Prev. 1999;4S:1-30.

45. Arbyn M, Anttila A, Jordan J, Ronco G, Schenck U, Segnan N, editors. European Commission. European Guidelines for Quality Assurance in Cervical Cancer Screening. 2nd ed. Luxembourg: Office for Official Publications of the European Communities; 2008. p. 1-291.

46. Promozione della salute della popolazione immigrata in Italia. In Accordo Ministero della salute/CCM - Regione Marche e coordinato dalla Regione Marche 2007-2009. 2009. http://www.ccm-network.it/documenti_Ccm/ prg_area5/Prg_5_Immigrati_metodologia.pdf.pdf. Accessed April 29, 2015.

47. Ronco S, Accetta G, Angeloni C, Arbyn M, Barzon L, Biggeri A, et al. HTA report: Ricerca del DNA di papillomavirus umano (HPV) come test primario per lo screening dei precursori del cancro del collo uterino. Epidemiol Prev. 2012;36(3/4 suppl 1):e1-e72.

48. Campari C, Zorzi M, lossa A, Giorgi Rossi P, Anghinoni E, Bietta C, et al. Survey GISCi sulle migranti nei programmi di screening cervicale. GISC 2014. Available on the web: http://www.gisci.it/documenti/documenti _gisci/GISCl-documenti-migranti-2014.pdf. Accessed April 29, 2015

49. Giorgi Rossi P, Camilloni L, Cogo C, Federici A, Ferroni E, Furnari G, et al. Health Technology Assessment Report: Methods to increase participation in cancer screening programmes. Epidemiol Prev. 2012;36(1 Suppl 1):1-104.

50. Spadea T, Bellini S, Kunst A, Stirbu I, Costa G. The impact of interventions to improve attendance in female cancer screening among lower socioeconomic groups: a review. Prev Med. 2010;50(4):159-64. doi:10.1016/j.ypmed.2010.01.007.

51. Palència L, Espelt $A$, Rodríguez-Sanz M, Puigpinós R, Pons-Vigués $M$, Pasarín $\mathrm{Ml}$, et al. Socio-economic inequalities in breast and cervical cancer screening practices in Europe: influence of the type of screening programme. Int J Epidemiol. 2010;39(3):757-65. Epub 2010 Feb 22

52. Carrozzi G, Sampaolo L, Bolognesi L, Sardonini L, Bertozzi N, Giorgi Rossi P, et al. Oncologic Screening test uptake: association with individual characteristics, geographic distribution, and time trends in Italy. Epidemiol Prev. 2015. In press.

53. Ronco G, Giorgi-Rossi P, Carozzi F, Confortini M, Dalla Palma P, Del Mistro A, et al. Results at Recruitment from a Randomized Controlled Trial Comparing Human Papillomavirus Testing Alone to Conventional Cytology as the Primary Cervical Cancer Screening Test. J Natl Cancer Inst. 2008;100:492-501.

54. Giorgi Rossi P, Bisanzi S, Paganini I, Di lasi A, Angeloni C, Scalisi A, et al. Prevalence of HPV high and low risk types in cervical samples from the Italian general population: a population based study. BMC Infect Dis. 2010;10:214

55. Giorgi Rossi P, Chini F, Borgia P, Guasticchi G, Carozzi FM, Confortini M, et al. Human Papilloma Virus (HPV), cervical cancer incidence and screening uptake: differences among Northern, Central and Southern Italy. Epidemiol Prev. 2012;36(2):108-19. 
56. Franceschi S, Herrero R, Clifford GM, Snijders PJ, Arslan A, Anh PT, et al. Variations in the agespecific curves of human papillomavirus prevalence in women worldwide. Int J Cancer. 2006;119(11):2677-84.

57. Giovannelli L, Vassallo R, Matranga D, Affronti M, Caleca MP, Bellavia C, et al. Prevalence of cervical human papillomavirus infection and types among women immigrated to Sicily, Italy. Acta Obstet Gynecol Scand. 2009;88(6):737-42

Submit your next manuscript to BioMed Central and take full advantage of:

- Convenient online submission

- Thorough peer review

- No space constraints or color figure charges

- Immediate publication on acceptance

- Inclusion in PubMed, CAS, Scopus and Google Scholar

- Research which is freely available for redistribution 